\title{
JOSEPH CONRAD'S THE END OF THE TETHER: LES JEUX SONT FAITS
}

\author{
Majda Šavle \\ University of Primorska
}

\begin{abstract}
The aim of this paper is to call attention to Conrad's rhetoric/spirit of play in his sea story The End of the Tether (1902). In my opinion, the games played by the characters of the narrative-above all Captain Whalley and the chief engineer Massy-belong among the four categories of games defined by a French sociologist Roger Caillois as: agôn, alea, mimicry, and ilinx. How good or bad the players are is a matter of the reader's perception of Conrad's fiction.
\end{abstract}

Keywords: game, play, rules, honour, winner

\section{INTRODUCTION}

According to a Dutch historian and cultural theorist Johan Huizinga, in the nineteenth century, science, philosophy, reformism, and above all economics, were all pursued in a "deadly earnest" fashion, while arts and letters were "emptier of the play-spirit than ever before." The French sociologist Roger Caillois agrees with Huizinga, emphasising that the phenomenon of play is viewed as "an occasion of pure waste: waste of time, energy, ingenuity, skill, and often of money." Christian Messenger, who investigates the rhetoric of play in fiction, adds that play has always been under attack by generations of Western capitalist writers, who have criticised it for not being "serious enough in the realm of acquisition, production, and consumption." ${ }^{3}$ However, the rhetoric of play is not just a matter of physical activity or an element of culture, but "a projection of the society's inner life, its understanding of human possibility," as stated by Oriard. He claims that play emerged as a rhetori-

\footnotetext{
${ }^{1}$ Johan Huizinga. Homo Ludens: A Study of the Play Element in Culture. Boston: Beacon, 1955, p. 192.

${ }^{2}$ Roger Caillois. Man, Play and Games. Chicago: University of Illinois Press, 2001, p. 125.

${ }^{3}$ Christian Messenger. Sport and the Spirit of Play in Contemporary American Fiction. New York: Columbia UP, 1990, p. 424.

${ }^{4}$ Michael Oriard. Sporting with the Gods: The Rhetoric of Play and Game in American Culture. New York: Cambridge UP, 1991, p. XI.
} 
cal emblem of culture, in opposition to civilisation, which was rational, bureaucratic, industrial, urban, i.e., "everything that thwarted the human spirit" ${ }^{5}$ at the turn of the twentieth century. Conrad's literary work confirms this. As a representative of the modernist novel of sensibility, Conrad developed a unique rhetoric of play. He proved himself a master of elaborate structure, sophisticated manipulation of point of view, and sustained irony. By setting his characters adrift from time to time, their words out of joint with their deeds, inner feelings conflicting with external appearances, or the "signifier with the signified," Conrad challenges the readers into producing various interpretations of his novels.

In order to confirm these assertions, I have framed my analysis of Conrad's rhetoric/spirit of play in The End of the Tether (1902) within Huizinga's and Caillois's definitions of play and games.

\section{WHAT IS PLAY?}

Huizinga considers play a voluntary activity or occupation executed within a certain fixed limit of time and space, according to rules freely accepted but absolutely binding, having its aim within itself and accompanied by feelings of tension, joy, and awareness, which are different from those of ordinary life. ${ }^{7}$ Caillois, who interprets many social structures as elaborate forms of a game-i.e., sees much of human behaviour as a form of play-questions Huizinga's definition as being both too broad and too narrow. ${ }^{8} \mathrm{He}$ argues that the part which is played by views as "an activity connected with no material interest," "excludes bets and games of chance, which play an important part in the economy and daily life of various cultures. In the opinion of Caillois, we can grasp the complexity of games by referring to four play forms: agôn, or competition (e.g., sports); alea, or chance (e.g., lottery, card games); mimicry, or role playing; and ilinx, or vertigo (altering perception). ${ }^{10}$ This article focuses on the first two: agôn and alea.

While investigating the rhetoric/spirit of play in The End of the Tether (1902), the concepts of sportsmanship and gamesmanship ${ }^{11}$ should be taken into consideration. In general, the spirit of sportsmanship refers to such virtues as fairness, self-control, courage and persistence, and has usually been associated with interpersonal relations

\footnotetext{
${ }^{5}$ Ibid., p. 443.
}

${ }^{6}$ Jamal Assadi. Acting, Rhetoric \& Interpretation in Selected Novels by F. Scott Fitzgerald \& Saul Bellow. New York: Peter Lang Publishing, 2006, p. 166.

${ }^{7}$ Johan Huizinga, op. cit., p. 13.

${ }^{8}$ Roger Caillois. "The Definition of Play and the Classification of Games." [In:] The Game Designer Reader: A Rules of Play Anthology. Eds. Katie Salen and Eric Zimmerman. Cambridge, MA: The MIT Press, 2006, p. 4.

${ }^{9}$ Roger Caillois. Man, Play and Games, op. cit., p. 13.

${ }^{10}$ Roger Caillois. "The Definition of Play and the Classification of Games," op. cit., p. 12.

${ }^{11}$ Michael Oriard. Sporting with the Gods: The Rhetoric of Play and Game in American Culture, op. cit., p. 29. 
requiring reciprocity in a fair treatment of others, maintaining self-control in dealing with others, and respect for both the authority and the opponent. Gamesmanship, on the other hand, implies the use of ethically dubious methods to gain an objective, or cleverly employed skills, or tricks, to succeed. In the sporting context, this relates to winning at any cost, i.e., acknowledging the rules but refusing to recognise the existence of any sort of code of conduct.

So, how do Conrad's heroes play? What games are they good at? What "type" of player do they represent-a cheater, a fair player, a gamesman, or a sportsman?

\section{THE END OF THE TETHER}

As Messenger puts it, "play remains the free individual's last best card in the deck, the one that may keep him alive in time and space by creating temporary structures of time and space that the individual can stand and learn in the larger game."12 The central figure of The End of the Tether, Captain Whalley, does precisely that. After losing most of his money in a bank crash, he sells his own barque the Fair Maid for $£ 700$. He sends his daughter Ivy $£ 200$ to become the landlady of a boarding house in Australia and invests the remaining $£ 500$ in an old coastal steamer the Sofala for three years and a sixth part of the profit, with a stipulation that if anything untoward happens, the money is to be paid back in its entirety to his daughter within three months. The agreement he signs with the owner, the chief engineer George Massy, sets up the rules of play between the captain and the owner, which is defined by Caillois as agôn, or competition, in which, as in combat, the "equality of chances is artificially created [...] within defined limits and without outside assistance." ${ }^{13}$ This form of play implies discipline and perseverance, sustained attention, appropriate training, assiduous application, and a desire to win. ${ }^{14}$ Captain Whalley has them allalmost. He is an honourable man: "he had handled many thousands of pounds of his employees' money and of his own; he had attended faithfully, as by law a shipmaster is expected to do, to the conflicting interests of owners, charterers, and underwriters" "15: and his physique matches his "stout-hearted and morally robust character"16: "he strolled on near the railings of the quay, broad-chested, without a stoop, as though his big shoulders had never felt the burden of the loads that must be carried between the cradle and the grave." ${ }^{\prime 17}$ A real sportsman, one would say, most probably a winner. $\mathrm{He}$ believes in his superiority and is highly motivated: "keeping his body and soul to-

${ }^{12}$ Christian Messenger. Sport and the Spirit of Play in Contemporary American Fiction, op. cit., p. 3.

${ }^{13}$ Roger Callois. "The Definition of Play and the Classification of Games," op. cit., p. 14.

${ }^{14}$ Ibid., p. 15.

${ }^{15}$ Joseph Conrad. The End of the Tether. [In:] Heart of Darkness \& Other Stories. Hertfordshire: Wordsworth Classics, 1999, p. 111.

${ }^{16}$ Patrick McGrath. "Conrad's The End of the Tether." The Conradian 2004, Vol. 32, No. 1, p. 43.

${ }^{17}$ The End of the Tether, op. cit., p. 122. 
gether (not a matter of great outlay), would enable him to be of use to his daughter." 18 What he lacks, though, is a fair opponent (he has to play against a gambler) and luck (he loses his possessions in a bank that has gone bankrupt; his son-in-law becomes a wheel-chair invalid; he himself is going blind).

Whalley's antagonist Massy does not believe in sportsmanship. He does not respect his rivals: "Everybody on board was his inferior-everyone without exception". 19 Even though he is an engineer, he negates the value of work, patience, experience, and qualifications, which the practice of agôn presupposes. He is insecure, suspicious, bitter greedy, and evil, a man corrupted by hankering after funds to invest in gambling. And yet, in the end he wins. Why? Because he ceases to be a gambler: "the great lottery had been the one inspiring fact of so many years of his existence," ${ }^{\prime 20}$ and becomes a gamesman: "his object had been to secure for himself as many ways as possible of getting rid of his partner without being called upon at once to pay back his share." 21

At first Massy plays a solitary game of alea, or chance, with no adversaries except fate. If alea is "a total disgrace, or absolute favour, granting the lucky player infinitely more than he could produce by a lifetime of labour, discipline, and fatigue," 22 Massy wins that favour. His is the second prize in the Manila lottery, and it is with this money that he buys the Sofala, bent on showing the world that "nobody on earth can put him out of his engine room now." ${ }^{23}$ But professionalization, application, and training play a limited role in alea. As a first engineer Massy cannot be the ship's captain, so he has to employ one. When fate brings Whalley aboard the Sofala, Massy is forced to play another game, the game Whalley imposes on him, the game of competition that has to be played within precise limits of time and space. In Messenger's view "competition may enlist play to drive for high stakes," 24 but it is improper to abandon or interrupt such a game without an imperative. Still, as Caillois points out, it is indeed tempting for someone who is used to submitting to fate, i.e., someone used to playing the game of alea - to try to predict the outcome of a game of agôn, or at least turn it to his favour. ${ }^{25}$ Massy goes even further by ruining it. Traditional morals, ideas, and beliefs have no value for him: he denounces the rules as absurd and conventional: "Who requires a captain? [...] The silly law requires a captain." ${ }^{26} \mathrm{He}$ bitterly resents Whalley for not being intemperate by saying: "you've been in the habit of drinking nothing but water for years and years," thus depriving himself of an opportunity to reject the contract: "how could I tell what was wrong about you?",

\footnotetext{
${ }^{18}$ Ibid., p. 123.

${ }^{19}$ Ibid., p. 142.

${ }^{20}$ Ibid., p. 172.

${ }^{21}$ Ibid., p. 173.

${ }^{22}$ Roger Callois. "The Definition of Play and the Classification of Games," op. cit., p. 133.

${ }^{23}$ The End of the Tether, op. cit., p. 205.

${ }^{24}$ Christian Messenger. Sport and the Spirit of Play in Contemporary American Fiction, op. cit., p. 426.

${ }^{25}$ Roger Callois. "The Definition of Play and the Classification of Games," op. cit., p. 134.

${ }^{26}$ The End of the Tether, op. cit., p. 170.
} 
hoping at the same time that Whalley's strategy will go wrong: "There's time for me to dismiss you before the three years are out-You will do yet something that will give me the chance to dismiss you." 27

So for a while Massy is crafty enough to keep waiting for the game to end. He counts on a sign of omen, or some sort of token, and he gets it, however not from the ambitious and scheming chief mate Sterne, who sees an opportunity to push Whalley out of his cabin by revealing to Massy that the latter is losing his sight, but from the drunken visionary, second mate Jack: "Let the old ship sink and the old chum starvethat's right. He don't go wrong-Massy $[\ldots]$ he's a genius $[\ldots]$ that's the way to win your money. Ship and chum must go." 28

And so Massy acts upon this. He commits an act of sabotage, hanging his jacket with iron bits in its side pockets near the ship's compass. Holger Nüstedt comments that by doing so, Massy expects an "unproblematic" running aground of the ship, ${ }^{29}$ with two positive outcomes for himself. He would get the insurance money (and he does) and his opponent would be disqualified for arranging a shipwreck (but he is not; he prefers to die rather than abandon the ship). When Massy takes action, he stops being a gambler who relies on pure fortune. By using a trick to defeat his rival, he becomes a gamesman rather than a sportsman who would play the best possible game of which he is capable within the fixed limits and according to the rules applied "equally to all." 30

Contrary to Massy, Captain Whalley becomes transformed from a fair playerfor "he had never lost a ship, or consented to a shady transaction" 31 - into a cheater who is pretending that nothing is wrong with his sight: "After all, he had never said anything misleading - and Captain Whalley felt himself corrupt to the marrow of the bones. ${ }^{32}$ Nevertheless, they both have something in common: they are solitary players.

Scholars, e.g., Paul L. Wiley, recognise the fact that despite a note of cynicism in his tales, such as The End of the Tether, it is difficult to regard Conrad as "an advocate of detachment," because his stories imply a necessity of "action" even when they demonstrate its futility in adverse circumstances or with certain types of characters. ${ }^{33}$ The passage from the old world of sail (order and rules, i.e., agôn) to the new one of steam (the modern world ruled by the law of survival, i.e., gamesmanship), inevitably brings about Whalley's tragic end. In consenting to become a partner of a lottery player, Whalley imagines that he can establish a compromise "between his high principles and claims of a world of brute struggle and lose only a little dignity and self-

${ }^{27}$ Ibid., p. 150.

${ }^{28}$ Ibid., p. 202.

${ }^{29}$ Holger Nüstedt. “Joseph Conrad's The End of the Tether: An Old Man's (Rite of) Passage.” EESE 1998, p. 7. Web. 15 July 2015.

${ }^{30}$ Roger Caillois. "The Definition of Play and the Classification of Games," op. cit., p. 132.

${ }^{31}$ The End of the Tether, op. cit., p. 111.

${ }^{32}$ Ibid., p. 139.

${ }^{33}$ Paul L. Wiley. “Conrad's Solitaries.” [In:] A Collection of Critical Essays. Ed. Marvin Mudrick. Englewood Cliffs, NJ: Prentice-Hall, 1966, p. 73. 
respect." ${ }^{34}$ But when chance deprives him of eyesight, the thought of his daughter Ivy leads him to acting falsely: "he had nothing of his own-even his own past of honour, of truth, of just pride, was gone [...] But what belonged to her, that he meant to save." ${ }^{35}$ As Nüstedt concludes, it is only because he does not follow his initial idea of revenge, and so cannot be exposed in his own reprehensible behaviour, that the court examining the accident can attribute it to an unusual set of the current, absolving Whalley of any fault. ${ }^{36}$ In consequence, his daughter obtains his share invested in the Sofala and Whalley's reputation remains intact, although, as noted by McGrath, "his virtue, his decency, and his honour were of no use other than to help him die well." 37

\section{CONCLUSION}

Produced at a time of crisis and transition in social and moral values of the modern Western society, Conrad's work impresses the reader not so much by "a statement of faith" or "a few elementary moral precepts" but rather by a "half scornful acceptance of the results of a sweeping away of beliefs." ${ }^{38}$ His manner of portraying even such serious themes as the effects of isolation and moral degradation by employing the rhetoric of play, allows Conrad not only to present strategies of survival, heroic/ anti-heroic codes, and states of being of his heroes, but also to expose life itself as game or play in his typically ironic manner. Because if "life is a kind of game, in which we have points to gain and competitors or adversaries to contend it," 39 and if play imitates life, the same is true about fiction. This remains in line with Messenger's proposal that an author's formal aim in any narrative is to allow the reader to recognize through the text a world that the author represents in "mimetic gesturing" while also challenging the reader with a "re-imagined subjective model of the world." ${ }^{40}$ It takes a master of the pen, though, like Conrad, to make the reader hear it, feel it, and, above all see it as it was at the end of the twentieth century.

\section{WORKS CITED}

Assadi, Jamal. Acting, Rhetoric \& Interpretation in Selected Novels by F. Scott Fitzgerald \& Saul Bellow. New York: Peter Lang Publishing, 2006.

${ }^{34}$ Ibid., p. 63.

${ }^{35}$ The End of the Tether, op. cit., p. 206.

${ }^{36}$ Holger Nüstedt. “Joseph Conrad's The End of the Tether: An Old Man's (Rite of) Passage," op. cit., p. 8.

${ }^{37}$ Patrick McGrath. "Conrad's The End of the Tether," op. cit., p. 46.

${ }^{38}$ Paul L. Wiley. "Conrad's Solitaries," op. cit., p. 71.

${ }^{39}$ In his book Unlearning Alejandro R. Jadad quotes from Benjamin Franklin's essay “The Morals of Chess" (1786), replacing the word chess with game, p. 36.

${ }^{40}$ Christian Messenger. Sport and the Spirit of Play in Contemporary American Fiction, op. cit., p. 8. 
Caillois, Roger. Man, Play and Games. Chicago: University of Illinois Press, 2001. . "The Definition of Play and the Classification of Games." The Game Designer Reader: A Rules of Play Anthology. Eds. Katie Salen and Eric Zimmerman. Cambridge, MA: The MIT Press, 2006. 122-155.

Conrad, Joseph. "Heart of Darkness" \& Other Stories. Hertfordshire: Wordsworth Classics, 1999. 107-219.

Huizinga, Johan. Homo Ludens. A Study of the Play Element in Culture. Boston: Beacon, 1955.

Jadad, Alejandro R. Unlearning. Incomplete Musings on the Game of Life and the Illusions That Keep Us Playing. Foresight Links Press, 2008.

McGrath, Patrick. "Conrad's The End of the Tether." The Conradian 32.1 (2004): 43-46.

Messenger, Christian. Sport and the Spirit of Play in Contemporary American Fiction. New York: Columbia University Press, 1990.

Nüstedt, Holger. “Joseph Conrad's The End of the Tether: An Old Man's (Rite of) Passage.” EESE 1998. Web. 15 July 2015.

Oriard, Michael. Sporting with the Gods: The Rhetoric of Play and Game in American Culture. New York: Cambridge University Press, 1991.

Wiley, Paul L. "Conrad's Solitaries." [In:] A Collection of Critical Essays. Ed. Marvin Mudrick. Englewood Cliffs, NJ: Prentice-Hall, 1966. 63-73. 